\title{
Job Satisfaction And Job Motivation Toward Performance Through Organizational Commitment
}

\author{
Dimas Agung Trisliatanto \\ Master Program Study of Human Resource \\ Development \\ Postgraduate School of Universitas Airlangga \\ Campus B. Jl. Airlangga No. 4-6 Surabaya, \\ Indonesia \\ e-mail : triztanagung90@gmail.com
}

\author{
Tan Evan Tandiyono \\ Master Program Study of Human Resource \\ Development \\ Postgraduate School of Universitas Airlangga \\ Campus B. Jl. Airlangga No. 4-6 Surabaya, \\ Indonesia \\ e-mail : tan_evan85@yahoo.co.id \\ Pristiandi Teguh Cahya \\ Master Program Study of Human Resource \\ Development \\ Postgraduate School of Universitas Airlangga \\ Campus B. Jl. Airlangga No. 4-6 Surabaya, \\ Indonesia \\ e-mail : unikdansolutif@gmail.com
}

Nur Anilawati

Master Program Study of Human Resource Development

Postgraduate School of Universitas Airlangga

Campus B. Jl. Airlangga No. 4-6 Surabaya, Indonesia e-mail : nuranilawati741994@gmail.com

\begin{abstract}
PT. Aneka Regalindo is engaging companies in furniture manufacturing that have experienced a decline in production output significantly over last 10 years. This decline has caused a decrease in productivity and employee performance. There is also a gap between the standards of compensation, job satisfaction, and job motivation. The purpose of this research is to examine the effect of job satisfaction and job motivation towards performance through organisational commitment. The method of this research study is explanative and quantitative. The finding results in addition to path analysis have concluded that job satisfaction does not influence performance through organisational commitment. Separately, job motivation has an influence towards performance through the organisational commitment of the production department.
\end{abstract}

Keywords: Job Satisfaction; Job Motivation; Performance; Organisational Commitment; Employee

Introduction

An important factor in optimising human resources that needs attention is performance. There are many factors that affect employee performance such as motivation, job satisfaction, stress level, the physical conditions of the work, the compensation system, job design, commitment, economic aspects, technical and other behavioural aspects [6]. PT. Aneka Regalindo is a company that produces 3 types of furniture consisting of rattan, wood, and aluminium with a large production capacity.

Many factors affect employee performance. The internal factors include intellectual ability, job discipline, job satisfaction and job motivation and the external factors include leadership style, job environment, compensation and the 
management system contained in the company [1]. Employees who do not get job satisfaction and job motivation will usually have a low morale, often daydreaming and suffering from fatigue and boredom, unstable emotions, frequent absences and busy activities that have nothing in relation to their work [2].
This can be observed from the data of the recapitulation of presence summary of Production Department PT. Aneka Regalindo Unit Rattan in Table 1 below.

\begin{tabular}{|c|c|c|c|c|c|c|}
\hline \multirow{2}{*}{ Month (Jan-Dec) } & \multicolumn{9}{|c|}{ Year } \\
\cline { 2 - 7 } & $\mathbf{2 0 1 0}$ & $\mathbf{2 0 1 1}$ & $\mathbf{2 0 1 2}$ & $\mathbf{2 0 1 3}$ & $\mathbf{2 0 1 4}$ & $\mathbf{2 0 1 5}$ \\
\hline Total Presence & 1.235 & 1.123 & 1.145 & 1.172 & 1.063 & 1.103 \\
\hline $\begin{array}{c}\text { Presentation of } \\
\text { Precence }\end{array}$ & $95,29 \%$ & $93,58 \%$ & $93,54 \%$ & $93,91 \%$ & $94,23 \%$ & $94,75 \%$ \\
\hline Amount of Employee & 108 & 100 & 102 & 104 & 94 & 97 \\
\hline Information & 31 & 39 & 35 & 33 & 29 & 26 \\
\hline Sick/ill & 18 & 28 & 26 & 29 & 19 & 17 \\
\hline Permission & 12 & 10 & 18 & 14 & 17 & 18 \\
\hline Without Permission & 61 & 77 & 79 & 76 & 65 & 61 \\
\hline Amount of Unpresence & & & & & \\
\hline
\end{tabular}

Source : Table 1 Presence Summary of Production Department Employee PT. Aneka Regalindo Rattan Unit start from 2010 Until 2015 : Employee Data of PT. Aneka Regalindo Rattan Unit 2016

In order, there is the amount of compensation (financial) received by the employees but unfortunately the amount of the salary received is often not in accordance with the size of the standard salary (in IDR), as seen in Table 2 below:

\begin{tabular}{|c|c|c|c|c|c|c|}
\hline $\begin{array}{l}\text { Level of } \\
\text { Employee }\end{array}$ & $\begin{array}{l}\text { Governor } \\
\text { Regulation } \\
\text { (2010) }\end{array}$ & $\begin{array}{l}\text { Accepted } \\
(2011)\end{array}$ & \multicolumn{2}{|c|}{$\begin{array}{c}\text { Governor } \\
\text { Regulation } \\
\text { (2011) }\end{array}$} & $\begin{array}{r}\text { Acce } \\
(201\end{array}$ & $\begin{array}{c}\text { Governor } \\
\text { Regulation } \\
\text { (2012) }\end{array}$ \\
\hline $\begin{array}{l}\text { Outsourcing } \\
\text { Vendor }\end{array}$ & \multirow{3}{*}{1.107 .000} & 800.000 & \multirow{3}{*}{\multicolumn{2}{|c|}{1.252 .000}} & 900. & \multirow{3}{*}{1.720 .000} \\
\hline $\begin{array}{l}\text { Outsourcing } \\
\text { Internal }\end{array}$ & & 900.000 & & & 1.000 & \\
\hline Settled & & 1.000 .000 & & & 1.100 .000 & \\
\hline Accepted (2013) & $\begin{array}{c}\text { Governor } \\
\text { Regulation (2014) }\end{array}$ & \multicolumn{2}{|c|}{ Accepted (2015) } & \multicolumn{2}{|c|}{$\begin{array}{c}\text { Governor } \\
\text { Regulation (2015) }\end{array}$} & epted (2016) \\
\hline 1.400 .000 & \multirow{3}{*}{2.190 .000} & \multicolumn{2}{|c|}{1.800 .000} & \multirow{3}{*}{\multicolumn{2}{|c|}{3.040 .000}} & 2.700 .000 \\
\hline 1.500 .000 & & 1.90 & & & & 2.800 .000 \\
\hline $1,600.000$ & & \multicolumn{2}{|c|}{2.000 .000} & & & 2.900 .000 \\
\hline
\end{tabular}

Source : Table 2 Employee Compensation of PT. Aneka Regalindo (IDR) : Employee Data of PT. Aneka Regalindo Rattan Unit and Governor Regulation from 2010 until 2016

There is also data about the labour turn-over PT. Aneka Regalindo’s rattan unit can be considered to be quite low as seen in Table 3 below:

\begin{tabular}{|c|c|c|c|c|c|c|c|c|c|c|}
\hline $\begin{array}{c}\text { Level of } \\
\text { Employee }\end{array}$ & $\begin{array}{c}\text { In } \\
\mathbf{( 2 0 1 1 )}\end{array}$ & $\begin{array}{c}\text { Out } \\
\mathbf{( 2 0 1 1 )}\end{array}$ & $\begin{array}{c}\text { In } \\
\mathbf{( 2 0 1 2 )}\end{array}$ & $\begin{array}{c}\text { Out } \\
\mathbf{( 2 0 1 2 )}\end{array}$ & $\begin{array}{c}\text { In } \\
\mathbf{( 2 0 1 3 )}\end{array}$ & $\begin{array}{c}\text { Out } \\
(\mathbf{2 0 1 3})\end{array}$ & $\begin{array}{c}\text { In } \\
(\mathbf{2 0 1 4})\end{array}$ & $\begin{array}{c}\text { Out } \\
(\mathbf{2 0 1 4})\end{array}$ & $\begin{array}{c}\text { In } \\
\mathbf{( 2 0 1 5 )}\end{array}$ & $\begin{array}{c}\text { Out } \\
(\mathbf{2 0 1 5})\end{array}$ \\
\hline $\begin{array}{c}\text { Outsourcing } \\
\text { Vendor }\end{array}$ & 14 & 10 & 7 & 9 & 7 & 12 & 9 & 4 & 8 & 6 \\
\hline $\begin{array}{c}\text { Outsourcing } \\
\text { Internal }\end{array}$ & 1 & 3 & 4 & - & - & 4 & 4 & 6 & - & 2 \\
\hline Settled & - & - & - & - & - & 1 & - & - & - & 1 \\
\hline $\begin{array}{c}\text { Amount of } \\
\text { LTO }\end{array}$ & 15 & 13 & 11 & 9 & 7 & 17 & 13 & 10 & 8 & 8 \\
\hline
\end{tabular}

Source : Table 3 Labour Turn-over of PT. Aneka Regalindo Production Department Rattan Unit : Employee Data of PT. Aneka Regalindo Rattan Unit 2016 
The labour turnover data related to the low job satisfaction and job motivation is usually due to a lack of vibrance, laziness, slowness and making mistakes and other negatives such as absenteeism, late entry to work and other things that affect employee performance [3].

\section{Methods}

The method of this research was explanative and quantitative. The quantitative explanative method is used to explain a generalisation, to explain the relationship of one variable with other variables, and to test the hypothesis in exploratory research using inferential statistics [4]. The sampling technique used is total sampling because of the amount of production department employees of PT. Aneka Regalindo rattan unit being 97 people. The conceptual definitions in this study are described as the following: job satisfaction, job motivation, performance and organisational commitment. This research used a validity test and reliability test [5].

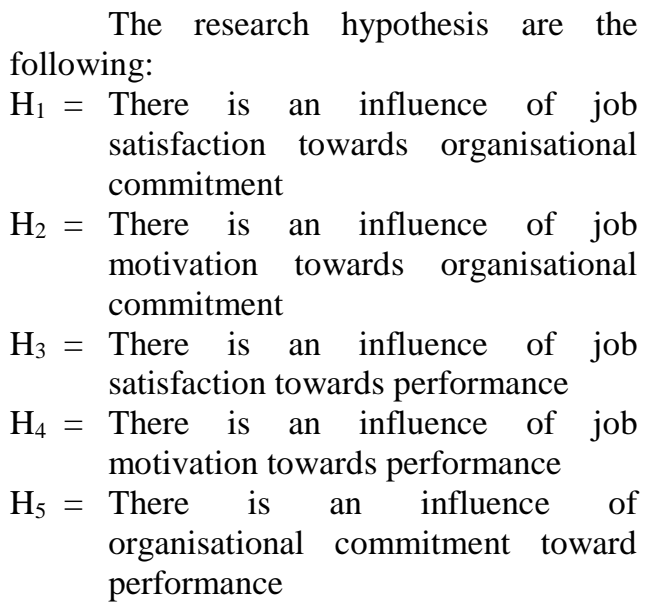
motivation towards performance

$\mathrm{H}_{5}=$ There is an influence of organisational commitment toward performance

The research instrument used in this research is based on the theory of job satisfaction, job motivation, performance and organisational commitment as a research variable. The data analysis techniques used are the classical assumption test and path analysis.

\section{Result and Discussion \\ Performance}

Performance is the result of the work performed by employees in an organisation in accordance with predetermined standards of success that have been determined by the organisation [6]. Performance can be measured through five dimensions: 1) Quality; 2) Quantity; 3) Knowledge and skills; 4) Timeliness and 5) Communication [7].

\section{Job Satisfaction}

Job satisfaction is one of the most important factors to get optimal work results [8]. Job satisfaction is a measure of sustainable human development process within an organisation [2]. The theory of Work Adjustment's development model measures 20 dimensions, which explains the needs of specific elements or specific amplifier conditions that are important in creating job satisfaction [9].

In this study, the researchers only used 10 dimensions to suit the needs of the stuudy. The factors include: (1.) Ability utilisation; (2.) Achievement; (3.) Activity; (4.) Advancement; (5.) Company policies and practices; (6.) Compensation; (7.) Coworkers; (8.) Moral values; (9.) Supervisionhuman relations and (10.) Working conditions.

\section{Job Motivation}

Motivation is a form of encouragement that exists in a person. The impetus comes from internal factors as well as external factors [10]. The key to understanding the process of motivation is within and is the link between needs, drivers and incentives [11]. The motivation is divided into two, namely internal and external. Internal motivation occurs when a person wants something, then he will try to perform a certain activity so that what he wants to be achieved can be, which includes (1.) Achievements; (2.) Recognition; (3.) Responsibility; (5.) Growth or the possibility to grow and (6.) Work Itself [13].

External factors arise when the individual does activities that get reciprocity from the outside to achieve their goals, which is influenced by (1.) Company policies and administration; (2.) Supervision; (3.) Wages, salaries or other benefits including incentives; (4.) Interpersonal relationships; (5.) Status; (6.) Job security and (7) Working conditions [12].

\section{Organisational Commitment}

Organisational commitment is a sense of identification, involvement, and loyalty 
expressed by an employee to the organisation shown through the attitude and willingness of a person towards a relatively strong company. They will also strive to achieve the organisational goals. The components of organisational commitment dimensions that can be measured includes (1) Affective commitment; (2.) Continuance commitment and (3.) Normative commitment [13].

\section{Interpretation}

Based on the analysis results, the findings can be shown within the below figure of a path diagram:

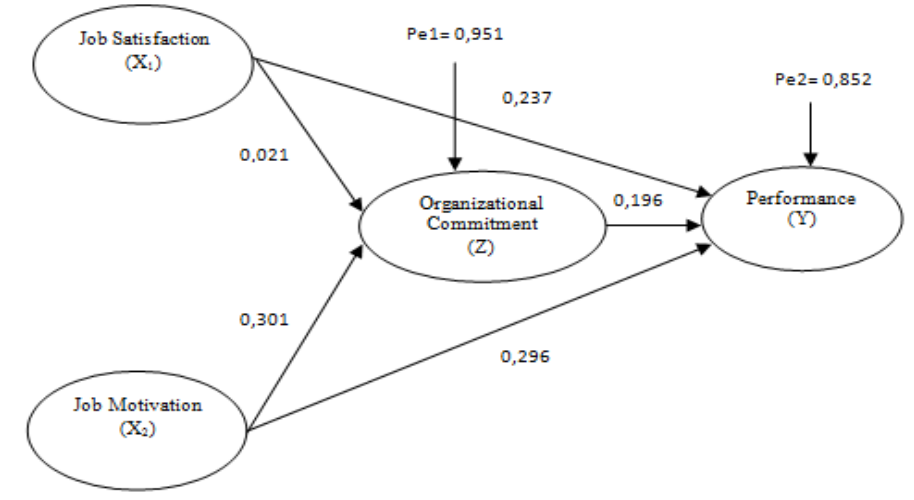

Fig. 1: The Analysis Results of Path Diagram: Primary Data, 2016

\begin{tabular}{|c|c|c|}
\hline Direct Influence & Influence Direction & Value of Influence \\
\hline Job Satisfaction $\left(\mathrm{X}_{1}\right) \Rightarrow$ Organizational Commitment $(\mathrm{Z})$ & Positive & 0,021 \\
\hline Job Motivation $\left(\mathrm{X}_{2}\right) \Rightarrow$ Organizational Commitment $(\mathrm{Z})$ & Positive & 0,301 \\
\hline Job Satisfaction $\left(\mathrm{X}_{1}\right) \Rightarrow$ Performance $(\mathrm{Y})$ & Positive & 0,237 \\
\hline Job Motivation $\left(\mathrm{X}_{2}\right) \Rightarrow$ Performance $(\mathrm{Y})$ & Positive & 0,296 \\
\hline Organizational Commitment $(\mathrm{Z}) \Rightarrow$ Performance $(\mathrm{Y})$ & Positive & 0,196 \\
\hline
\end{tabular}

Table 4: Value of Direct Influence : Primary data, 2016

\begin{tabular}{|c|c|c|}
\hline Indirect Influence & Influence Direction & Value of Influence \\
\hline Job Satisfaction $\left(\mathrm{X}_{1}\right) \Rightarrow$ Organizational Commitment $(\mathrm{Z}) \Rightarrow$ Performance $(\mathrm{Y})$ & Positive & $0,021 \times 0,196=0,004$ \\
\hline Job Motivation $\left(\mathrm{X}_{1}\right) \Rightarrow$ Organizational Commitment $(\mathrm{Z}) \Rightarrow$ Performance $(\mathrm{Y})$ & Positive & $0,301 \times 0.196=0,058$ \\
\hline
\end{tabular}

Table 5:Value of Indirect Influence : Primary data, 2016

\section{Conclusion}

After data processing with the statistical method and analysis, this research has yielded the following conclusions.

The Influence of Job Satisfaction Towards Organisational Commitment

The influence of job satisfaction toward organisational commitment is not significant with a value of 0,021 (Table 4); the first hypothesis is not proven. This is opposed to the theories about the influence of job satisfaction towards organisational commitment:"High job satisfaction contributes to organizational comitment..." [14] and "another factor that can affect performance is employee job satisfaction as defined below, employee job satisfaction is fulfilled or not their desire to work...." [15].

\section{The Influence of Job Motivation Towards Organisational Commitment}

The influence of job motivation toward organisational commitment is significant with a value of 0,301 (Table 4); the second hypothesis is proven. This fits with the theories about the influence of job motivation towards organisational commitment. "Implementation of the overall job motivation program successful positively affect to worker's commitment" [16]. And "theoretically that the job motivation is the driving force that resulted in an organization member willing to mobilize the ability in the form of skills and skills, energy and time to organize various activities that are their responsibility and fulfill their obligation in order to achieve the various organizational goals that have been predetermined..." [17]. 
The Influence of Job Satisfaction Towards Performance

The influence of job satisfaction towards performance is significant with a value of 0,237 (Table 4); the third hypothesis is proven. This fits with the theories about the influence of job satisfaction towards performance: "......the performance was divided into two parts, namely in role and extra role performance where in role performance is the performance that affect (antecedent) job satisfaction while the performance role was the performance which has influenced by job satisfaction therefore the opinion of previous researcher on whether job satisfaction was influenced or affect the performance considered depending on which performance correctly ......" [6].

\section{The Influence of Job Motivation Towards Performance}

The influence of job motivation towards performance is significant with a value of 0,296 (Table 4); the forth hypothesis is proven. This fits with the theories about the influence of job motivation towards performance: "......job motivation had a significant effect to employee performance where It was showing that the increased of job motivation will improve employee performance [2].

\section{The Influence of Organisational Commitment Towards Performance \\ The influence of organisational commitment towards performance is significant with a value of 0,196 (Table 4); the fifth hypothesis is proven. This fits with the theories about the influence of organisational commitment towards performance: "....if the employee's organizational commitment was high It would affect to the employee performance improvement whereas if the employee commitment is low then the performance is also low..." [1].}

\section{The Influence of Job Satisfaction Towards Performance Through Organisational Commitment}

Table 5 shows that organisational commitment is not a mediating variable which influences job satisfaction and the performance of production department employees in PT. Aneka Regalindo's rattan unit. This opposes with the theories about the influence of job satisfaction towards performance through organisational commitment: ".....the positive variables on job satisfaction were the type of job itself, the salary/wage, the opportunity for promotion, their boss and the coworkers can be fulfilled then the commitment to the organization would arise well, so job satisfaction had influencing to performance through organizational commitment...." [17].

The Influence of Job Motivation Towards Performance Through Organisational Commitment

Table 5 shows that organisational commitment is a partial mediating variable which influences job motivation towards the performance of the production department employees of PT. Aneka Regalindo in the rattan unit. This opposes with the theories about the influence of job satisfaction towards performance through organisational commitment: "....the great motivation of each individual, both leader and employee was what can ultimately gave each example a good example so as to create job satisfaction and foster a sense of commitment in the organization where the mutual ownership appeared to be an important part in It, so It could provide morale and impact on the performance of employees who were getting better too...." [18].

\section{Acknowledgments}

The researchers would like to express their gratitude to God and to thank the parties involved in this research. Thanks go to my beloved family who always encouraged my spirit, the lecturers of Airlangga University, the employees in this research who became the respondents, and my colleagues who helped in funding this research.

\section{References}

[13] Allen, N. J. \& Meyer, J. P. Commitment In The Workplace: Theory, Research, and Application (Ed. Rev). Thousand Oaks, CA: Sage Publishing, Inc, 2013.

[1] Benkhoff, B. "Ignoring Commitment Is Costly: New Approaches Establish The Missing Link Between Commitmen and Performance". Human Relations Journal. Vol. 26, No. 1; pp. 16 - 30, 2012 
[2] Carmeli, A., \& Freund. "Work Commitment, Job Satisfaction, and Job Performance : An Empirical Investigation". Academic Research Library International Journal of Organization Theory and Behaviour. Vol. 7 No. 3; pp. 31-39, 2014

[9] Cascio, W. F. Managing Human Resource ( $4^{\text {th }}$ Ed.). Colorado: Mc Graw-Hill, 2013

[10] Chen, I. J., \& Paulraj, A. "Towards of Theory Human Resource Management: The Construct and Measurement". Journal of Human Resource Management. Vol. 22, pp. 139-150, 2016

[8] Crossman, S. A., \& Zaki, A. "Job Satisfaction and Employee Performance of Lebanese Banking Staff'. Journal of Management Psychology. Vol. 18 (4); pp. 39-44, 2013

[7] Dale, T. A. Human Resource Development: Performance. Jakarta: Elex Media Komputindo, 2013

[16] Fields, M. W. \& Thacker, J. W. "Influence of Quality of Work Life On Company and Union Commitment". Academy of Management Journal. Vol. 35, No. 2; 439 - 450, 2002

[5] Ghozali, I. Statistic Test. Semarang: UNDIP Press, 2012

[12] Hezberg, F. One More Time: How Do You Motivate Employees?. Boston: Harvard Business Press, 2012

[6] MacKenzie, S. B. "Effects of Organizational Citizenship Behaviors and Productivity On Evaluations of Performance At Different Hierarchical Levels In Sales Performance". Journal of The Academy of Marketing Science. Vo. 27; pp. 396 - 410, 2014

[18] Noe, R. M. Human Resource Management $\left(4^{\text {th }}\right.$ Ed). America : McGraw Hill Companies, 2003

[14] Northcraft, G. \& Neale, M. A. Organization Behavior: A Management Challenge ( $2^{\text {nd }}$ Ed.). The Dryeden Press Harcourth Brace College Publisher, 2004

[3] Okpara, J. O. "Personal Characteristics as Predictors of Job Satisfaction: An Explanatory Study of IT Managers in Developing Country". Journal Information Technology \& People. Vol. 4 (17) : 327-338, 2014

[15] Timmreck, T. C. "Managing Motivation and Developing Job
Satisfaction In The Health Care Work Environtment". The Health Care Manager; ABI/INFORM Research. Vol. 20, Number 1, page $42-61,2001$

[11] Sharma, D. M. "Diversity of Influences About Compensation Towards Motivation in Industry of Bangladesh". Journal Management Innovation Research New Delhi. Vol. 21, No. 17; pp. 131-142, 2013

[4] Sugiyono. Research Method: Quantitative, Qualitative, and $R \& D$. Bandung : Alfabeta, 2014

[17] Warsi, S. Fatimah, N. \& Shamim, A. S. "Study On Relationship Between Organizational Commitment and Its Deteminants Among Private Sector Employees of Pakistan”. International Reviews of Business Research Papers. Vol. 5, No. 3; pp. 339 - 410, 2009 